\title{
Structural studies of human selenoprotein synthesis
}

\author{
Miljan Simonović a \\ a Department of Biochemistry and Molecular Genetics, College of Medicine, The University of \\ Illinois at Chicago, Chicago, IL 60607, USA, msimon5@uic.edu
}

I joined the Steitz group as a postdoctoral fellow in 2003 and spent 5 incredible years under Tom's mentorship. The 'Yale years' were formative in many ways and consequently had left a deep imprint on my career. Perhaps the most remarkable feature of Tom's modus operandi was the he encouraged scientific freedom and independence of people who worked with him. Collaborative projects were often forged, and Tom would not be aware of such endeavors until after first scientific fruits were born. Herein, I will describe how one such collaboration that had been initiated while I was in Tom's laboratory led me to a path of studying a set of intriguing basic scientific questions to this day [1-8]. The overall goal of these studies is to understand at the structural level how humans synthesize the amino acid selenocysteine and how is that amino acid incorporated into nascent selenoproteins.

\section{References}

[1] Palioura S, Sherrer RL, Steitz TA, Söll D, Simonović M (2009). Science 325, 321-325.

[2] Palioura S, Herkel J, Simonović M, Lohse A, Söll D (2010) Biol Chem 391, 771-776.

[3] Rigger L, Schmidt RL, Holman KM, Simonovic M, Micura R (2013). Chemistry 19, 15872-15878.

[4] French RL, Gupta N, Copeland PR, Simonović M (2014). J Biol Chem 289, 28783-28794.

[5] Puppala AK, French RL, Mathies D, Baxa U, Subramaniam S, Simonović M (2016). Sci Rep 6, 32563.

[6] Dobosz-Bartoszek M, Pinkerton MH, Otwinowski Z, Chakravarthy S, Söll D, Copeland PR, Simonović M (2016). Nature Commun 7, 12941.

[7] Holman KM, Puppala AK, Lee JW, Hyun L, Simonović M (2017). RNA 23, 1685-1699.

[8] Simonović M \& Puppala AK (2018). Biochim Biophys Acta, doi:10.1016/j.bbagen.2018.03.018. 